\title{
Laurentius Boëtius den yngre.
}

\author{
Af Sogneprast L. Vesten, sulsted.
}

Siden jeg her i Aarbogerne for 1927 skrev min lille Opsats om Præsterne Boëtius i Vilstrup, har jeg faaet en Fornemmelse af, at der rundt om i Landet findes en ikke helt ringe opmarksomhed for den Slags Undersøgelser. I hvert Fald har jeg modtaget et ret anseligt Antal Anmodninger om yderligere Oplysninger. Fælles for de allerfleste Henvendelser har været Opfordringer til at give Besked om den ældste af Magister Jorgen Boyes Sønner, Laurentius, der, som det synes, forst træler frem i Dagens Lys 1613 som Sognepræst i Løgumkloster for efter 6 Aars Præstevirksomhed der at gaa i Graven.

Paa disse Sporgsmaal har jeg mattet svare, at jeg kun grumme lidt havde at meddele om ham, som kunde historisk bevises, men at han jo heller ikke synes at have særlig historisk Betydning ud over det at være Jørgen Boyes og Sara Meigers Son.

Naar jeg alligevel af disse Foresporgsler har taget Anledning til at overveje, hvad man med nogen $\mathrm{hi}$ melighed kan tillade sig at fremsætte om den yngre Lorents Boyes Livsforhold, har jeg taget min Tilflugt til hans Slæegtsforhold i lidt videre Forstand, da disse formentlig vil kunne hjælpe os til i store Trak at angive Omrilsene for hans Levnedsløb.

Hvad véd vi med Sikkerhed om Lorents Boye?

Vi véd, 1) at han var Jørgen Boyes ældste Søn; allerede det, at han havde samme Navn som Farfaderen, siger os det, og yderligere fortælles det af Hans Oldendorph, der var Præst i Haderslev santidig med Jørgen Boye; Oldendorph kalder ham i sin Dagbog "primogenitus". Vi ved, 2) at han 1583 var præsteviet, hvilket fremgaar af en gammel Bog, som Thode har haft fat $i$, og hvori Lorents Boye maaske selv har skrevet en Notits, som Rhode ganske vist har misforstaaet. Vi ved, 3) at han dode som Prast i Løgumkloster 1619; det fortæller Rhode os, og det bekræftes af Kraffts husumske Kirke- og Skolehistorie. Vi ved, 4) at han var gift med en Præste- 
latter Magdalene Selmer; Rhode siger, at hun var "fra Smalsted«. Vi ved, 5) at han havde en Sorn Jorgen Boye, der var Præst i Hellevad og Egvad; det fortæller Rhode og Jensen.

Mere véd vi ikke.

Men Punkt 4, lıans Agteskab med Maglalene Selmer, aabner en Dor paa Klem for os. Og hvad jeg igennem demme Dorsprakke har troet at kumme skimte af hans Levnedslob, skal jeg paa de folgende sider fremsætte og søge at gore sandsynligt.

Vi vil forgæves søge Lorents Boye blandt dem, der fra Haderslev Skole er afgaaede til et eller andet Lniversitet. Det er hidtil ikke lykkedes at fastslaa hans Navn i nogen Universitetsmatrikel. Ikke desto mindre maa han have gennemgaaet en skoleforberedelse og et derefter folgende Universitetsstudium, siden han opnaaede at blive Prist i den lutherske Kirke.

Sin Skoleuddannelse har han faaet i Bordesholm Gymnasium i Holsten. Universitetsuddannelsen har han modtaget i Rostock eller København.")

Grunden hertil er den, at Lorents Boye straks efter Faderens Død er komnen bort fra Hạderslevegnen for at blive opdraget videre af Moderens Slargt. Heri maa ogsaa søges en Forklaring paa det Forhold, at han ikke kom til at folge efter sin Fader som Præst i Vilstrup: han var bleven fremmed for Haderslevegnen og for Resten af sin Levetid knyttet til de gottorpske Landsiele.

Lad os se lidt paa Moderens Slægt; den er ret mærkelig og satte sine ret tydelige Spor i den Tids Rørelser; dette gælder saavel Sara Meigers Fader og hendes to Brødre Albert og Samuel som en anden Gren af samme Afstamning, hvortil f. Eks. Geografen og Korttegneren Johannes Meier hører." )

Sara Meigers Fader Johan nes $M$ e i g e r eller Meier begyndte sin Præstegerning ved Katrinekir-

") Jeg har her i min $\Lambda$ fsideshed ikke kunnet faa I,ejlighed til at gennemgaa Hofmeisters "Matrikel der Universität Rostorks«, og Kobenhavns Universitetsmatrikel for den Tid findes ikke.

*) Jeg statter denne Paastand om Slaxgtsforbindelse paa de Kendsgerninger, at begge Meierslægterne stammer fra Hamborg, og at Navnene Johannes, Albert og Samuel er fælles for dem. 
ken i Hamborg; han sluttede sig tilligt til Luthers Reformation og var den forste Prast i Hamborg, der giftede sig. Efter Anmorlning fra Nordstrand blev han i Aaret 1525 sendt dertil for at prædike Reformationens Tanker, og han har faaet Hidersnavnet "Strandfrisernes Reformator". Han var Præst ved Pelvorm Kirke til 1532, da en Vandflod, der anrettede en Del Ulykker, fik ham til at tage Bestemmelse om at vende tilbage til Hamborg. Saa langt kom han imidlertid ikke; da han naaede til Rendsborg med sin Familie, modtog han en indtrængende Opforlling til at moltage Stillingen som Sogneprast ved Mariekirken der i Byen og Provst i Rendsborg. Amt; han blev i Rendsborg til sin Dosd 1561. Som et Vidueshyrd on den Anseelse, han nod, maa vi hetragte det, at Kong Christian den tredje i Aaret 1541 beordrede ham til at visitere og reformere de bestaaende Klosterstiftelser i Slesvig, Holsten og Stormarn overensstemmende med Kirkeordinansens Forskrifter."

Af Provst Meiers to Simner var A l b e r t den xuldste; han blev folt paa Pelvorm 15:8 og blev ligesom den yngre Broder sendt til Kobenhavns Universitet, hvilket var ret usidvanligt i de Tider, da Holstenere og Slesvigere saa at sige udlelukkende drog til de norltyske Universiteter, sarlig til Rostock. Albert Meier var et matentatisk snille, og 1550 foreslog Kongen Universitetet at ansatte ham som Professor i Matematik; men Professorerne mente, lian var lovlig ung, han var jo kun 22 Aar. I Aaret 1553 blev han Præst i Lindholn i Buking Herred, og der docle han 1603. Hans matematiske og mekaniske Forsog bevirkede, at hans Sogneborn nærnest betragtede hain som en Troldmand. Han var gift med en Datter af Frederik Johansen fra Lindholm, der under Ditmarskertoget i 1559 var Fyrsternes Overingeniør, og let er rimeligt, at Svigersøn og Svigerfader sammen har drøftet og planlagt de Forholdsregler, der burde tages overfor Vanskelighederne ved at fore en Hær gennem det uvejsonme Ditmarsken.

Den yngste Søn S a m u e l blev født 1532, rimeligvis efter Ankomsten til Rendsborg. Efter fuldendte Studier i København var han i nogen Tid Pradikant

* Inländ. Registrant, Rigsankivet. 
i Hollæuderbyen paa Amager, men blev derefter Prast i Nortorf, der er Nabosogn mod Syd til hans hjemlige Rendsborg. Nortorf Kirke og Præstegaard ligger midtvejs mellem Rendsborg og Neumünster og er bleven historisk bekendt derved, at i Nortorf Kirke fandt den 28. og 29. April 1559 ret Mode Sted, hvorved Kong Frederik den anden, Hertug Hans af Haderslev og Hertug Adolf af Holsten tog Beslutning om Toget mod Ditmaskerne.") Mange Aar efter mindedes $\mathrm{Hr}$. Samuel endnu, at Kongen ved den Lejlighed havde været hans Gæst i Nortorf Præstegaard, og ved Frederik den andens Dod 1588 skrev han et Iigt om den afdode Herres "salige Afsked". - Mest bekendt er Hr. Samuel vel bleven ved sin omfangsrige Bog med den mærkelige historiske Eksempelsamling, der har Titlen "Nucleus Historiarum", og som han tilegnede Christian den fjerde." ) Hr. Samuel dode forst 1612 .

- Da Provst Jorgen Boye i Begyndelsen af Maj 1569 blev begravet i Haderslev, maa vi antage, at der mellem Enken og hendes to Brodre er bleven plejet Raad om, hvorledes hun skulde ordne Fremtiden bedst for sig og sine Børn For den mldste af Drengene, Lorents, er Udfaldet bleven det, at han enten straks er rejst med Morbroderen hjem til Nortorf eller snart efter er bleven sendt derned og overgivet til Præstekonen Gundels moderlige Omsorg og den lærde Præsts Vejledning under det udvidede Skolearbejde, som nu skulde til at begynde.

Øst for Nortorf Kirke og Præstegaard strakte sig den Gang i nord-sydlig Retning en frodig Skovstrækning, bag hvilken de gamle Klosterbygninger $\mathbf{i}$ Bordesholm fjælede sig ved Bredden af en fiskerig sx. Klosteret, der havde huset Augustiner Kor-

-) Omtrent. 310 Aar efter Fyrstembet vandt Nortorf igen et vist historisk 1 y. Det var i Nortorf, at det store holstenske Folkemude, der samlede omtrent 3(k) Mennesker, lilev afholdt den 14. September 184ti som l'rotest mord Christian den ottendes aabne Brev af $\$$. Juli samme Aar om Arvefolgen i det danske Monarki.

*) I "IIjst. Tidsskr.« 3. VI. 503, Noten er denne Bog fejlagtig angivet som skrevet af Broderen Albert i Lindholm. Denne har derimod skrevet en Slags Rejsehaandhog, der udkom i mange Udgaver, hvilket viser, at den er hleven flittig brugt af de mange unge, der rejste til Udlandet for at uddanne sig. 
herrer, var i Aaret 1566 i bleven lukket af Hertug Hans i Haderslev og derefter omdannet til en Lærdomsskole i Lighed med Skolen i Haderslev, der i de samme Aar blev genskabt. Skolen i Bordesholm fik log ikke saa lang en Levetid, som susterskolen i Haderslev har faaet. Efter en kort Blomstring kom den $i$ et ynkeligt Forfald og lukkedes nøjagtig 100 Aar efter sin Opstaaen samtidig med, at Christian Albrecht Universitetet i Kiel blev aabnet.

Her i Bordesholm gamle Klosterkirke stod det berømte Brüggemannske Alter, der 16ibi efter Skolens og Kirkens Lukning blev fort til Slesvig Domkirke og opstillet i Hojkoret, hvor det endnu vidner om den ypperste Træskærerkunstner i Norden, Hans Brüggemann fra Walsrode i Lüneburg, der døde som Almisselem i Husum.

Under disse Forhold maa vi forestille os, at Lorents Boyes Lngdomstid er henrunden, dels i Præstehjemmet i Nortorf, dels i Bordesholm Skole, til hvis forste Aargange han altsaa nua have hort, og det er som næunt Grunden til, at man forgæves søger lıam blandt Haderslev Skoles Elever. Da Tiden kom til Universitetsstudierne, sendte Hr. Samuel ham enten til Rostock eller maaske snarere til Københavns Lniversitet, hvor Nortorfpræsten selv havde tilbragt 0 Lngdomsaar.

Fra Nortorf Naboskab hentede Lorents Boye ogsaa sin Hustru. Rhodes Bemærkning om, at han var gift med Præstedatteren Magdalene Selmer "fra Smalsted «, er det vanskeligt at bringe i Overensstemmelse med Virkeligheden. Ganske vist findes der et Schmalstede i det nuværende Bordesholm Kirkesogn; men Bordesholm opstod forst som selvstændig "Gemeinde" 1736 derved, at Dele af Nortorf og Brügge Sogne blev samlede om den gamle Klosterkirke, der havde staaet lukket siden 1665. Før 1736 horte Schmalstede til Brügge, men der vides intet $\mathrm{om}$, at Præstegaarden i Brügge nogen Sinde har ligget i Schmalstede, og der kendes heller ingen Præst af Navnet Selmer i Brügge.

Tæt nordøst for Brügge ved den smukke Bothkamp Sø, der har Aflob gennem den spæde Ejderbæk, ligger Kirkebyen Barkau, som vel officielt hedder Kirchbarkau. Her var Mat thias si el mer 
Prest i en Aarrække, indtil Forholdene efter Præstegaardens Brand blev mindre tilfredsstillende for ham, hvorfor han 1579 blev Prest i Westensee, Nabosogn til Nortorf, der ligger lige syd for Westensee. Matthias Selmer dode 1588. Magdalene Selmers Barndom og Ungdom er derfor henrunden i Barkau og Westensee; men vi kan jo gerne for Rhodes Skyld føje til: i Narlıeden af smalsted.

- Ldenfor Lindholm og Risum Sogne i Boking Herred laa den (iang Halligen "Osvalde"; Johannes Meier kalder den paa sine Kort Oserwalıt. Paa denne Hallig træffer vi i 1590'erne Lorents Boye som Præst; det er naturligvis Morbroderen Albert i Lindholm, der har faaet Sostersonnen anbragt der lige udenfor sine egne Sognegrænser. Navnet Osvalde") betyler "Skoven ved Mundingen", den laa nemlig lige i Larkaaens og Soholmaaens Delta, og Navnet siger os, at den i sin Till har veret opfyldt af de udstrakte Lindeskove, der har givet Lindholm, Risum og Klokris deres Navne, og hvoraf man endnu finder Rester ved Gravning i Egnens Moser. Navnet fincles vist slet ikke mere bevaret, og Halligen selv er forlangst bleven landfast med det hagved liggende $\mathrm{B} \sigma$ king Herred; nu har sognet længe haft Navnet Faaretoft.

Hvornaar Lorents Boye er kommen til Halligen i Vesterhavet, vides ikke sikkert. Men da Broderen Jørgen i Aaret 1583 blev indsat som Præst i Vilstrup, har Lorents aflagt et Besøg i Fadrehjemmet og er ved den Lejlighed betegnet med et $" \mathrm{Hr}$.« foran sit Navn, hvilket angiver, at han paa det Tidspunkt var en præsteviet Mand. Denne Oplysning har vi fra Rhode, der beretter, at der fandtes en gammel Bog. som havile tilhort Jørgen Boye den æeldre, og i rlemne Bog var der skrevet, at i Aaret 1583 skænkede Hr. Laurentius Boëtius Bogen til sin Svoger Hr. Noa Simonis i Hoptrup, og at det skete i Vilstrup Kirke. Paa den Tid har Lorents Bnye vel altsaa været Præst paa Osvalde.

*) $\gg$ ()s betyder Mundingen af et smalt Vandlub on urtales omitrent som Os i Ordet Lampe os, Os fra en ryfende lysetande. ()shy ved Hadersler, hed oprindelig Oshy eller efter Udtalen Oesby, Byen ved Fjordens Munding. Oslo i Nolge betyder Byen ved Loelvens Munding. 
I Aaret 1596 navnes imidlertid en anden Mand som Præst paa Halligen, nemlig den Riggel Sonniksen, der med hele sin Husstand druknede under Vandfloden i 1634.

Hvor er da Lorents Boye flyttet hen?

Jeg mener, at han allerede paa det Tidspunkt er flyttet til Logumkloster, der ligesom Tønder Amt hørte til de gottorpske Besiddelser. En stotte for denne Antagelse afgiver formentlig en Fortegnelse over Præster, der har underskrevet det af Hofpræst Jacob Fabricius udarbejdede Prastelofte.") Og der e $r$ i Aaret 1596; sket et Præsteskifte i Logumkloster; der nævnes blot ikke, hvem der kom i stedet for den, som drog bort. Præst i Nørre Løgum og Løgumkloster, som den Gang var forenede, var den 73-aarige Lavge Troelsen, der i nogen Tid havile haft en Peter Fabricius til Kapellan; Hr. Peter blev inidlertid 1596 kaldet til Præst og senere Provst i Broager, bvor han i Tidens Lob blev en meget ilde anset Mand. Det kunde med Grund ventes, at en 73 -aarig Præst ret snart maatte yde clen menneskelige Natur sin Skyldighed ved at da, og Lorents Boye kan derfor godt have anset det for et fordelagtigt Bytte at f)ytte fra sin lille Vesterhavs til stillingen som "Adjunctus et successor" (Kapellan og Efterfolger) hos Hr. Lavge. Havde han kunnet forudse, at den ganle Præst skulde blive 90 Aar, vilile han maaske have betænkt sig. Lavge Troelsen døde forst 1613, hvorved Lorents Boye, der nok af Gavn længe havle været den virkelige Sognepræst, nu ogsaa blev det af Navn; han var det kun i 6 Aar; thi 1619 døde han.

Der er intet, som tyder paa, at Lorents Boye har været mere end et ganske almindeligt Menneske og en jævn Præstemand saadan, som de fleste var og er. Gennem en Datter af hans Son Jørgen, der var Præst i Hellevad og Egvad, blev han Stamfader til en stor Kreds af Præster, Prastekoner og Skolemænd, der hver paa sit Sted har fyldt sin Plads.

- Da Lorents Boye forlod Hjemmet, beholalt Moderen de yngre Born hos sig; der har varet mindst tre foruden Lorents, en Pige og to Drenge. Datteren blev siden gift med Prasten Noje Simonsen

") Krafft: Husum lirkehist. 
i Hoptrup, og Sønnen Jørgen blev Prest i Vilstrup. Den yngste Søn hed Johannes efter Morfaderen i Pendsborg. Om denne Johannes Boëtius véd vi, at han i Aaret 1582 blev indskrevet som Student ved Universitetet i Wittenberg; efter endt Studium blev han - rimeligvis gennem sine to ansete Morbrodres Indflydelse hos Hertugen Adolf eller Filip - Diakon i Hamm paa Nordstrand. Hamm gik helt til Grunde ved Vandfloden 1634. Embedet som Diakon i Hamm havde Menigheden ingen Myndighed over; det blev besat af Landsherren sammen med Overhovedet for en enkelt indflydelsesrig Slægt der paa Stedet; men den, som Hertugen særlig onskede valgt, kunde han vel ogsaa regne med at faa ansat. Johannes Boye var kun Prrest nogle ganske faa Aar; han døde 1588. 